\section{Understanding fatness in the public sphere of young students: social representations and emotional response}

\author{
Entendiendo la gordura en la esfera pública de \\ estudiantes jóvenes: representaciones sociales \\ y respuesta emocional
}

\section{Entendendo a gordura no universo público dos jovens: representações sociais e resposta emocional}

Nahia Idoiaga Mondragon 1

Maitane Belasko Txertudi 1

doi: 10.1590/0102-311X00197917

\begin{abstract}
This study examines how youth collectively represent fatness and determines the emotions it arouses. Understanding how fatness is socially constructed by young people is crucial to create programs that better deal with it. A free association exercise elicited by the word "fatness" was answered by 200 people of the Autonomous Community of the Basque Country (Spain), and the content was analyzed by its lexicon using Alceste software. The results showed that health-related representation of fatness was mostly descriptive, and it was not connected to risky or any emotional response. But fatness was also completely represented as a social pressure issue related to stigmatization and highly correlated with negative emotions, such as sadness, insecurity, embarrassment, anguish, lonesomeness, pity or anger. That is, risky and negative emotions were linked to social non-acceptance, and not with health problems. Thus, the conclusion is that fatness is transmitted from fear and not from a positive construction of the health.
\end{abstract}

Emotions; Obesity; Body Weight; Young Adult

\author{
Correspondence \\ N. Idoiaga Mondragon \\ Departamento de Psicología Evolutiva y de la Educación, Euskal \\ Herriko Unibertsitatea, Universidad del País Vasco. \\ Barrio Sarriena s/n, Leioa 48940, España. \\ nahia.idoiaga@gmail.com \\ ${ }^{1}$ Euskal Herriko Unibertsitatea, Universidad del País Vasco, \\ Leioa, España.
}


The population overweight is one of the most important challenges of the $21^{\text {st }}$ century 1 . In Western society, obesity has become an unstoppable epidemic and has direct social implications. Therefore, this is one of the most concerning issues, particularly among young people 1 . In this study we analyze how they understand overweight in their everyday thinking, contributing to the state of the art on the subject with a perspective that considers both emotional and social aspects involved.

This research investigates shared representations of overweight. From the perspective of social representations, beyond scientific knowledge about an issue (overweight in our case), people understand and share common ideas through social representations. The social representation of a specific crisis is determined by historical events and contemporary symbols used to familiarize the threat and transform it into everyday thinking 2,3 .

Previous research has pointed out that, on one hand, overweight is socially represented as a health problem mainly related to a sedentary lifestyle and a bad nutrition 4 . But, on the other hand, it is also represented in aesthetic terms, in which beauty suffers as weight increases, reducing a person's attractiveness 5 . This aesthetic issue has its impact particularly among young people, for whom fitting or not fitting into their clothes dictates whether they feel fat or not 6,7 .

Body weight has also been associated with social relationships in terms of perceived group exclusion or inclusion 6 . In fact, obesity is seen as a status cue 8 and obese people suffer discrimination in every area of their lives, including education, employment, healthcare, and in intimate relationships 9. Even though the term obese evokes stronger negative evaluations than the term fat 10 , fatness has also come to be strongly feared in our society 11.

Research in the field of social representations 12,13 highlights the role that emotional context plays in symbolic thought and its relevance in making a topic recognizable and understandable. Social Representation Theory proposes that emotions do not distort cognition, while understanding that both are a multifaceted response 12,14 in health crises.

Research around emotions and fatness or obesity has mainly focused on emotional predictors of obesity 15,16,17,18 or emotional eating 19,20,21. Nevertheless, little research analyzes what specific emotional responses are evoked in social representations of fatness. Previous researches in this area show that fatness has been associated with psychological components, such as anxiety, depression, embarrassment or discrimination ${ }^{4}$. In addition, disgust or negative emotions have predicted prejudice and discrimination toward individuals with obesity 22,23. Fat people have also been described as ugly and unhappy ${ }^{5}$.

In the Autonomous Community of the Basque Country (Spain), where our research unfolds, the last Public Health Survey 24 found that $51.8 \%$ of people were overweight (body mass index - BMI > $25 \mathrm{~kg} / \mathrm{m}^{2}$ ) and that $47.2 \%$ would like to lose weight. However, these results change dramatically among young people (18-26 years). While $17.1 \%$ of youth were found to be overweight, $30.9 \%$ of them would like to lose weight. These results suggest that the shared representation of fatness among young people is especially important and critical.

The main goal of this paper is to study the impact that fatness has on the public consciousness of youth and their emotional response. The objective is to analyze fatness as a social issue and to determine the emotions it arouses. Understanding how fatness is socially constructed by young people is crucial to create programs to better deal with it.

Due to the worldwide dimension of the obesity epidemic, fatness is likely to be represented as a health problem, caused particularly by a sedentary lifestyle and poor nutrition. Fat people are also expected to be represented as people with a strong surrounding negative emotional charge. This research aims to study such emotions in depth and determine whether they are connected to any subjective or interpersonal factors.

In the same vein, fatness is likely to be represented as an aesthetic issue linked with ugliness. We will try to precise the factors that determine this assumption and ascertain whether they are socially promoted. In addition, we also want to inquire into the emotional responses that are associated with this aesthetic factor. 


\section{Method}

\section{Sample}

Two hundred people participated in this research. The sample was composed by first-year students in their first month in the University (September), since our goal was to analyze young students recently graduated from high school. A convenience sample was presented to Spanish students - University of the Basque Country (65\%), Mondragon University (25\%) and Deusto University (10\%) - of three different degrees - psychology (40\%), childhood education $(31,5 \%)$ and primary education $(28,5 \%)$. $61 \%$ of the students were women and the average age of the participants was 18.89 years $(\mathrm{SD}=2.22$ with an age range of 18-23 years). Considering the BMI of the participants, $7 \%$ of these students had an insufficient weight, $81 \%$ a normal weight, $10 \%$ were overweight and $2 \%$ were obese.

\section{Design}

To perform this investigation, participants were asked in a questionnaire to provide a free response to the following single question: "What do you think and feel when you hear the word 'fatness'?". The question was answered in a face-to-face context, for which the researchers went to in the different universities. After answering the question, the youth were also asked about their age, gender, university, degree, height and weight.

To proceed with a content analysis of shared representations of fatness, the free word association technique was used. The Social Representations Theory argues that analysis of free associations across groups 25,26 and contexts 27 provides a clear procedure to identify the "figurative nucleus" of the representation of diseases.

Alceste software (http://www.image-zafar.com/Logicieluk.html, Toulouse, France) for lexical analysis 28,29 was used to analyze the corpus of the texts, eliminating problems of reliability and validity in the text analysis 30,31. Previous studies have shown that this technique is useful and apt for analyzing content of social representations 32 , concluding that emergent results are consistent with those proposed by classic research in this area.

Firstly, the initial corpus is divided into elementary contextual units (ECUs), which have the approximate length of a sentence or two (30-50 words) 33 . The corpus is analyzed considering the presence of whole words in the ECUs. ECUs and the reduced forms are used to create a contingency table, which shows the vocabulary distribution per ECU. From this contingency table, a squared distance matrix is generated, meaning that two ECUs are close if they share some of the words analysed 31.

Subsequently, a descending hierarchical cluster analysis is performed on this distance table, which yields classes of ECUs that best differentiate the vocabulary. In doing so, this software assists in the interpretation of texts, extracting classes of words that co-occur and that are best differentiated from other classes.

Following previous research with Alceste 34 , the most significant vocabulary in each class was directed under three criteria: (1) an expected value of the word greater than 5; (2) association proof of the chi-square tested against the class $\left(\chi^{2} \geq 3.89 ; \mathrm{p}=0.05\right.$; $\left.\mathrm{df}=1\right)$; and (3) the word must be mainly within that class with a frequency of $50 \%$ or more. Once identified, these "lexical universes" are associated with "passive" variables (independent variables), providing a chi-square statistic. In this case, the passive variable was the weight of the participants (insufficient, normal, overweight and obese).

As a last step, and as a complementary analysis, Alceste also makes a multiple correspondence factor analysis produced from the descending hierarchical cluster analysis.

\section{Results}

The results section is structured into two subsections. First, the shared representations about fatness are examined focusing on the free association exercise results, and then, the emotional response, associated with those representations, is specified. 


\section{Shared representations of fatness}

The full corpus had 11,752 words, and 1,707 were unique words. Specifically, the descending hierarchical analysis divided the corpus into 333 ECUs, and 4 types of classes were extracted from the most significant vocabulary in each class. None of these classes was significantly related to the weight type of the participants. Results of the analysis can be observed in Figure 1.

Results showed two main clusters: the first one defines what fatness is and who is defined as fat (classes 1 and 2), while the second one is more related to how fat people are seen and how they should act (classes 3 and 4). Following the division of the cluster analysis, in the first main cluster, the first class, "fatness" (30.17\%), is the most descriptive class. It reflects a description of fatness as an important health problem that can be a big obstacle in life, as described in the next ECU: "It is a bad state of health that can become a big problem. Whatever the case, it is a shame because fat people are not physically able to enjoy life" (Men, normal weight; $\chi^{2}(1)=31$ ). Further, this class points out that bad nutrition and a sedentary lifestyle are its main causes: "It is produced by eating too much food and not practicing sports. Sometimes you must lose weight for health reasons. Being fat is unhealthy and it is essential to eat healthily and practice a lot of sports" (Woman, normal weight; $\chi^{2}(1)=19$ ); "When fatness becomes obesity it can cause health problems. In many cases, the causes are a poor diet or eating too much unhealthy food” (Woman, normal weight; $\left.\chi^{2}(1)=31\right)$.

Linked to the first class, appears the "larger size clothes" (7.85\%) class, highlighting that one of the consequences of fatness is the difficulty in finding clothes that fit. Therefore, people that do not fit their clothes are defined as fat people. This class argues that regular size clothes often do not fit fat

\section{Figure 1}

Hierarchical clustering dendrogram of free association that describes the social representations about fatness with the most frequent words and the words with the greatest association $\left(\chi^{2}(1) ; p<0.001\right)$.

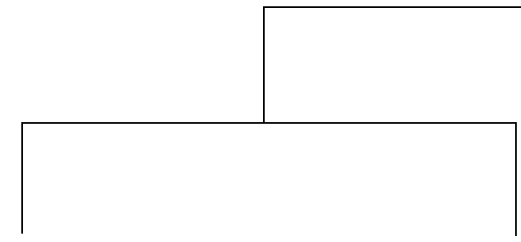

Class 1: the fatness $(30.17 \%)$

\begin{tabular}{|l|c|c|}
\hline \multicolumn{1}{|c|}{ Word } & F & $\chi^{\mathbf{2}}$ \\
\hline Sport & 33 & 62.31 \\
\hline Food & 30 & 43.34 \\
\hline Nutrition & 20 & 38.91 \\
\hline Health & 30 & 31.38 \\
\hline Fatness & 28 & 23.95 \\
\hline Problem & 21 & 17.29 \\
\hline Bad & 14 & 16.42 \\
\hline Fat & 16 & 16.85 \\
\hline Consequence & 10 & 12.01 \\
\hline Hamburger & 5 & 11.82 \\
\hline
\end{tabular}

Class 2: larger size clothes $(7.85 \%)$

\begin{tabular}{|l|c|c|}
\hline \multicolumn{1}{|c|}{ Word } & F & $\chi^{\mathbf{2}}$ \\
\hline Larger & 13 & 148.42 \\
\hline Size & 9 & 109.71 \\
\hline Girl & 6 & 39.21 \\
\hline Special & 7 & 36.49 \\
\hline Clothes & 6 & 34.76 \\
\hline Obsession & 5 & 25.35 \\
\hline Shop & 5 & 25.35 \\
\hline Belly & 5 & 19.19 \\
\hline Pain & 5 & 14.52 \\
\hline Ugliness & 5 & 7.29 \\
\hline Sadness & 6 & 4.54 \\
\hline Sorrow & 5 & 2.67 \\
\hline Anguish & 5 & 2.67 \\
\hline
\end{tabular}

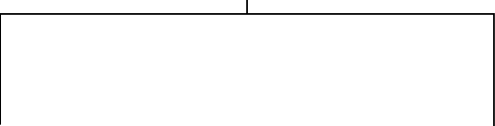

Class 3: how are fat people seen by themselves and society? (38.10\%)

\begin{tabular}{|l|c|c|}
\hline \multicolumn{1}{|c|}{ Word } & F & $\chi^{\mathbf{2}}$ \\
\hline Herself & 18 & 41.35 \\
\hline Embarrassment & 23 & 25.08 \\
\hline Opinion & 11 & 18.74 \\
\hline Anxiety & 6 & 15.74 \\
\hline Society & 6 & 15.74 \\
\hline Social & 6 & 15.74 \\
\hline Feel & 6 & 11.84 \\
\hline Insecurity & 9 & 11.50 \\
\hline Insults & 9 & 11.50 \\
\hline Lonesomeness & 5 & 7.77 \\
\hline Judged & 5 & 6.81 \\
\hline
\end{tabular}

Class 4: to lose weight (23.88\%)

\begin{tabular}{|l|c|c|}
\hline \multicolumn{1}{|c|}{ Word } & F & \multicolumn{1}{c|}{$\chi^{2}$} \\
\hline Fats & 22 & 23.79 \\
\hline Pity & 23 & 23.76 \\
\hline Slim & 11 & 22.49 \\
\hline Slim down & 6 & 12.00 \\
\hline Difficult & 5 & 9.96 \\
\hline Bulimia & 8 & 9.90 \\
\hline Anorexia & 8 & 9.90 \\
\hline Kilos & 8 & 7.76 \\
\hline Depression & 5 & 6.72 \\
\hline Anger & 5 & 6.72 \\
\hline Pressure & 5 & 6.72 \\
\hline
\end{tabular}


or overweight people well: "I am sick of going shopping with my friends and hearing again and again that their clothes do not look right, or they cannot fit in them. We want a homogeneous society where a few sizes fit everyone" (Woman, insufficient weight; $\chi^{2}(1)=31$ ). Some of the most relevant ECUs argue that fitting or not fitting well in clothes is what makes them feel fat or not, and also whether their "regular clothes" fit them properly or not: "What most infuriates me is that my friends and I feel fat because clothes sizes in the regular stores are becoming smaller. So, we are always having to go for a larger size. My mates wear large-sized clothes and sometimes the whole size issue makes us feel awful (Woman, normal weight; $\chi^{2}(1)=28$ ).

The second main cluster is more related to how fat people are usually seen and how they usually act. The first class, "how are fat people seen by themselves and by society?" (28.1\%), has two groups of ECUs. Firstly, there are the responses of fat people (or people that feel fat), explaining how they see themselves and how they feel about their condition. Some of the main ECUs are: "I have a great lack of self-confidence. Insecurity. Being fat makes me really hurt and I feel bad. My physical image really embarrasses $m e$, and I have loads of complexes. So, my life is pretty sad" (Woman, normal weight; $\left.\chi^{2}(1)=29\right)$; "People look at me and insult me, so my self-consciousness increases. The insults and the lack of confidence lower my self-esteem. I'm not comfortable with my body. I mean, like, I don't look at myself in the mirror. If I don't like myself, who will? It is sad to have these feelings about gaining weight, but I can't feel otherwise" (Woman, overweight; $\chi^{2}(1)=$ 24). Secondly, there are also many ECUs in this class describing fatness as a social problem or as a problem aggravated by society: "People look at you funny and sometimes say things to hurt you. I feel ashamed, because society looks down on fat people. They are frowned upon by society (Man, overweight; $\left.\chi^{2}(1)=27\right)$; "In society today, there is too much social pressure against fat people, especially against fat women. If you are a fat woman, society marginalizes you. I've been overweight all my life and I have always been directly or indirectly marginalized. Such social pressure causes many physical and mental illnesses and punishes us for being as we are (Woman, normal weight; $\chi^{2}(1)=27$ ); "Fat-phobia. Being fat is not having an obesity problem, it is much more about the pressure of aesthetics. The obese have always been the outcasts of society. Overweight people who do not have health problems must also put up with cruel taunts and insults. It is more a reflection of social stereotypes, an aesthetic pressure and the objectification of the body in this developed society. Everyone is overweight if we follow the established canons" (Woman, normal weight; $\left.\chi^{2}(1)=24\right)$; "It is a shame that society has such a negative attitude toward fatness. The main promoters of this are the mass media because they use these ideas against fat people. In consequence, fat people become ashamed of their own bodies" (Men, normal weight; $\left.\chi^{2}(1)=24\right)$.

Lastly, the "to lose weight" class (23.88\%) is associated with this second cluster. This class focuses on how fat people are constantly pressured to lose weight. This pressure is described as a very powerful lobby in our society. Here are some of the typical ECUs: "I am afraid of eating and afraid of putting on weight. I always want to lose weight and it is a torture. I would like to be thin and I envy girls who are thin and do not have to make any effort to be so. Why am I fat? I feel sorry for myself" (Woman, overweight; $\chi^{2}(1)=$ 16); "A fat person needs to lose weight and wants to be thin. Other people do not like fat people, so we need to go on diets to lose weight. The fact is, it is not acceptable today to be fat and we are always prisoners to dieting. And even if we lose weight, we then put it on again and end up going crazy! We cannot go on like this forever!" (Woman, normal weight; $\chi^{2}(1)=12$ ).

\section{Shared emotional response of fatness}

To deeply analyze emotional responses regarding fatness, we firstly identified emotional significant words related to each class. Results showed that the first class, "fatness", is more descriptive and not excessively related to emotions, while the rest of the classes are much more emotional.

Starting from the second class, obsession $\left(\mathrm{F}=5 ; \chi^{2}=25.35\right)$, pain $\left(\mathrm{F}=5 ; \chi^{2}=14.52\right)$, ugliness $(\mathrm{F}=5$; $\left.\chi^{2}=7.29\right)$, sadness $\left(\mathrm{F}=6 ; \chi^{2}=4.54\right)$, sorrow $\left(\mathrm{F}=5 ; \chi^{2}=2.67\right)$ and anguish $\left(\mathrm{F}=5 ; \chi^{2}=2.67\right)$ were linked to the "larger size clothes" class. Anxiety $\left(\mathrm{F}=6 ; \chi^{2}=15.74\right)$, feel $\left(\mathrm{F}=6 ; \chi^{2}=11.84\right)$, insecurity $\left(\mathrm{F}=9 ; \chi^{2}=\right.$ 11.50), lonesomeness $\left(\mathrm{F}=5 ; \chi^{2}=7.77\right)$ and judged $\left(\mathrm{F}=5 ; \chi^{2}=6.81\right)$ were linked to the "how are fat people seen by themselves and society?" class. Finally, pity $\left(\mathrm{F}=23 ; \chi^{2}=23.76\right)$, depression $\left(\mathrm{F}=5 ; \chi^{2}=\right.$ 6.72) and anger $\left(F=5 ; \chi^{2}=6.72\right)$ were linked to "lose weight".

The multiple correspondence factor analysis derived from the descending hierarchical cluster analysis (Figure 2) illustrates the previous results.

The words that most prominently contribute to the factors are projected on the plane that intersects factors 1 ( $\mathrm{X}$ axis) and 2 (Y axis). Factor 1 polarized, on the one hand, fatness as a disease or health 
Figure 2

Multiple correspondence factor analysis that describes social representations about fatness produced from the descending hierarchical cluster analysis.

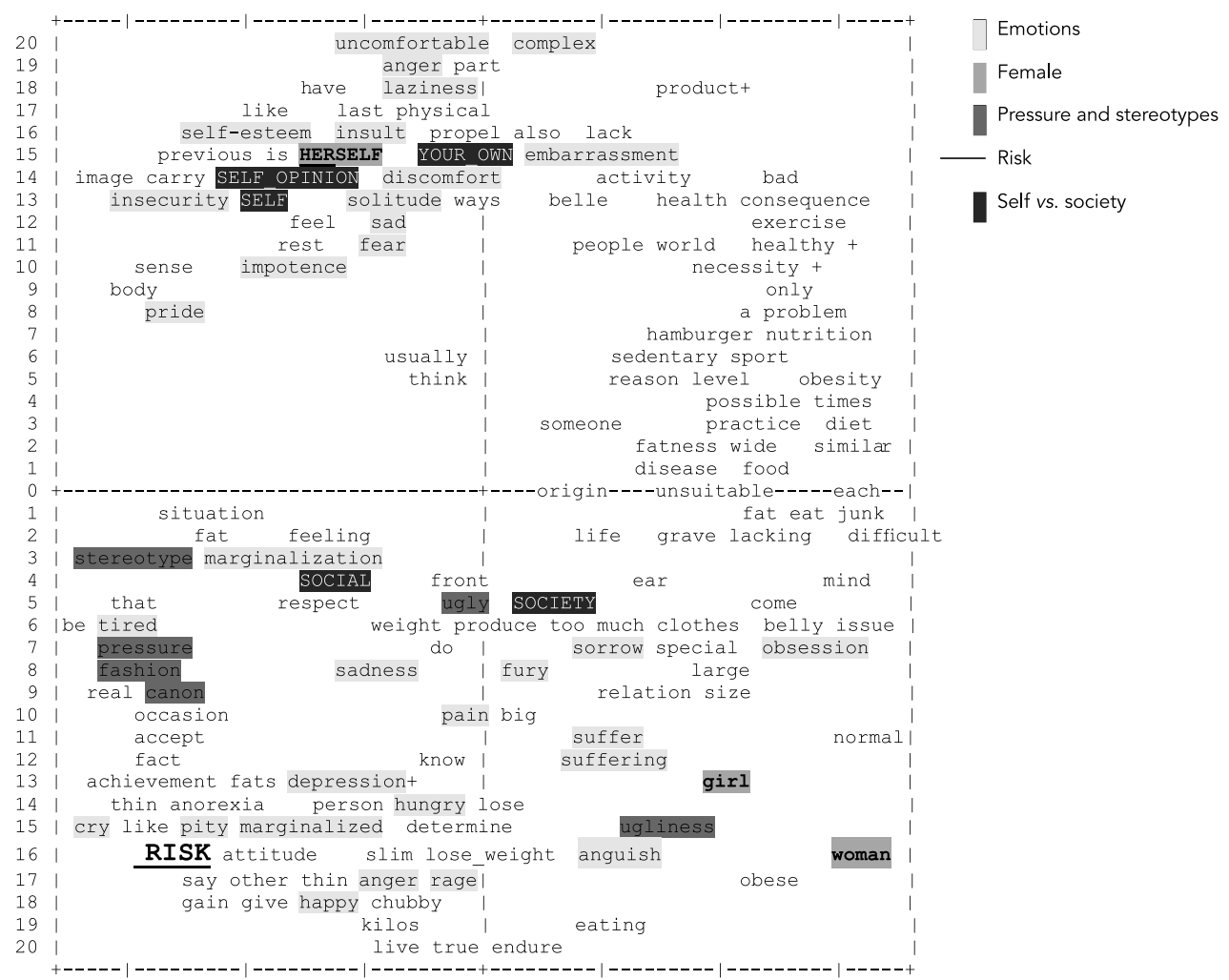

problem (disease, obesity, health, etc.) with words that describe its causes and consequences: disease, obesity, activity, food, junk, sedentary, etc. These words are mainly descriptive and are distant to the emotional words. Then, on the other hand, the social actors of fatness are presented: society and the representation of fat people. In factor 2 , the distribution of those social actors is more clear, analyzing exactly which emotional response or words are connected to each other. Therefore, on the top of the axis we have the representation or the self-representation of fat people, that is, how they see themselves (Herself, your own, self-opinion, self, etc.). The image of fat people is linked with emotional words, such as uncomfortable, complex, anger, laziness, self-esteem, embarrassment, discomfort, insecurity, solitude, sad, fear or impotence. Then, as this axis descends, we can see society (society, social, etc.) also described as a promoter of pressure and stereotypes (stereotype, ugly, pressure, fashion, canon, ugliness, etc.),relating it to emotional words associated with suffering, such as marginalization, tired, sadness, pain, sorrow, obsession, suffer, suffering, depression, cry, pity, marginalized, anguish or happy, and others linked with anger, such as fury, hungry, anger or rage. The word risk is also on this side of the axis.

Lastly, we should also highlight that in this multiple correspondence factor analysis, female word references have emerged, in particular: herself, girl or women. These words have appeared both in connection with society and with self-image. 


\section{Discussion}

This research has provided important evidence about why the concern about fatness is part of contemporary youth culture. Our results highlighted the multidimensionality of social representations of fatness, describing it as a subjective problem, as well as an interpersonal issue in which emotions are a key factor to construct the understanding from everyday thinking.

Social representations regarding fatness among youth have an epistemological description of this issue. As in previous researches, fatness is understood as a health problem developed by lack of activity and poor diet 4 . This health correlated argument is only descriptive and reflects no specific emotional component in the results. Medical-scientific representation of the disease, therefore, does not emotionally affect lay thinking about fatness.

But this epistemological description is not the only way to determine what fatness is. As in previous research 6,7, "fitting your clothes or not" is also described as a crucial factor for people to feel fat or not. "Not fitting your clothes" means "feeling fat" and, in consequence, is strongly related to ugliness. Therefore, this fact is described as an obsession among young people and as responsible for causing pain, sadness, sorrow and anxiety. Furthermore, these emotions relate to social and interpersonal issue, revealing that this "fitting" issue is more than an aesthetic problem, since fitting certain sizes of clothes has become a way to be socially accepted 6 .

In fact, our results have demonstrated that feeling bad for feeling fat 35 is much more associated with social pressure than with self-health or self-comfort. That is, fatness is described as a marginalization factor by society and, as a result, creates solitude or loneliness. People feel judged (and sometimes insulted) for their weight, causing embarrassment, anxiety, fear, sadness, and insecurity, and they describe these direct effects on their self-esteem. That is, when disassociating the idea of fatness as a health problem, a surrounding negative emotional charge is created due to the non-acceptance of fatness in our society.

This fat-phobia representation is, moreover, especially associated with girls or women. Anti-fat or pro-slim representation and pressure are deeply grounded in references to the female figure. In fact, feeling fat has been considered as "a woman's shame" with direct negative consequences on women and their weight 36 , producing emotional distress 37 .

Feelings of pity for fat people also emerged in the results. Pity is an ambivalent emotion, comprising both compassion and sadness, resulting from appraising another's negative outcome as uncontrollable 38. Previous research found that groups stereotyped as low on competence but high on warmth elicit pity 39 . Therefore, people not only that link fatness with marginalization, but they assume that fat people are not sufficiently competent to cope with this issue and, even worse, people who feel fat also share this assumption and feel sorry for themselves. Indeed, these feelings of pity become more salient in contexts where fat people attempt to lose weight. Slimming is described as strong social pressure, rather than a necessity or a personal goal 40 , and is highly correlated with the discourse around diseases, such as depression, anorexia or bulimia, rather than with a healthy lifestyle or questions of nutrition.

It is a fact that in modern societies the obesity index is increasing but, meanwhile, the concern about fatness is also increasing. Public health campaigns have played a significant part in attempting to solve the crisis, and research has been devoted to examining their impact and effectiveness $41,42,43$. Along with the results, something that these campaigns should consider is the negative emotional representation of fatness combined with social stigma. The results have shown that young people feel fatness as a tough issue to cope with at an emotional level and as a factor of verificalearned helplessness 44 . That is, negative shame and emotional vulnerability related to fatness is mostly connected with social non-acceptance, and not with health problems.

Fatness is an important issue, especially among young people and the coming generations, however the results have shown that young people think of fatness with fear and not as a positive construction of health. Fatness and obesity should not be treated from the perspective of aesthetic problems, stigma troubles or marginality issues. Firstly, the acceptance of the diversity of body weight in the population should be highlighted, and, secondly, the risk of medical conditions stemming from being overweight or obese should be defined 45 , since recent research suggests that health risks vary significantly between overweight and obesity 46 . Therefore, social representations of fatness must ultimately 
be re-described and rebuilt from a healthy life perspective. As a society, we must not succumb to the current pattern of negative emotional construction of fatness, since it only aggravates the situation.

As far as this research has investigated the social representations of young people, if we want to work fatness from a positive construction perspective, this issue must be covered in all educational stages (from preschool to university). In fact, the education professional's role in establishing healthy routines in children is well-proven $47,48,49$. Based on this research, and framed in education and health psychology, two key tasks are detected in schools. On the one hand, it is important to bring to students the importance of a balanced diet and physical exercise. Once the school incorporates these values. healthy habits among children and adolescents can be promoted 50 . On the other hand, schools must also be a protected area for the diversity of the body. That is, schools should especially promote a respectful environment to all students 50,51. For this, teaching students from an early age to love and accept themselves is essential, and school is decisive in all these processes.

However, the educational system is not the only one that should be responsible for coping with stereotypes related to the lean and healthy body. Family and society also have relevant part in the reproduction of these prejudices. Therefore, there are also other social actors equally important in shaping values about the body and about the relationship that young people are establishing with food, for example, the large communication, entertainment and food corporations, as well as the fashion industry. This study shows an inflection in the value system of our societies that presupposes, among others, regulatory measures that support the emancipation of people.

Obesity is one of the most important challenges facing modern society. Understanding the patterns linked to these epidemic and knowing how it is cognitively represented and emotionally faced gives us an added value tool to comprehend how young people incorporate fatness within their everyday thinking and provides information on how this important issue can be appropriately managed.

\section{Contributors}

Both authors worked on all stages of the article's production.

\section{References}

1. World Health Organization. Obesity: preventing and managing the global epidemic. Geneva: World Health Organization; 2000.

2. Moscovici S. The phenomenon of social representations. In: Farr RM, Moscovici S, editors. Social representations. Cambridge: Cambridge University Press; 1984. p. 3-71.

3. Moscovici S, Duveen G. Social representations: explorations in social psychology. New York: New York University Press; 2000.

4. Collipal EL, Godoy MP. Social representations of obesity in pre-university and university youth. Int J Morphol 2015; 33:877-82.

5. Malterud K, Ulriksen K. Norwegians fear fatness more than anything else: a qualitative study of normative newspaper messages on obesity and health. Patient Education and Counselling 2010; 81:47-52.

6. Stenzel L, Saha L, Guareschi P. To be fat or thin? Social representations of the body among adolescent female students in Brazil. International Education Journal 2006; 7:611-31.

7. Trautmann J, Lokken-Worthy S, Lokken KL. Body dissatisfaction, bulimic symptoms, and clothing practices among college women. J Psychol 2007; 141:485-98.

8. Vartanian LR, Silverstein KM. Obesity as a status cue: perceived social status and the stereotypes of obese individuals. J Appl Soc Psychol 2013; 43:319-28. 
9. Puhl RM, Brownell KD. Bias, discrimination, and obesity. Obes Res J 2001; 9:788-905.

10. Vartanian LR. "Obese people" vs."fatpeople": impact of group label on weight bias. Eat Weight Disord 2010; 15:195-8.

11. Windram-Geddes M. Fearing fatness and feeling fat: encountering affective spaces of physical activity. Emot Space Soc 2013; 9:42-9.

12. Höijer B. Social Representations Theory: a new theory for media research. Nordicom Review 2011; 32:3-16.

13. Smith N, Joffe H. How the public engages with global warming: a social representations approach. Public Underst Sci 2013; 22:16-32.

14. Joffe H. Risk: from perception to social representation. Br J Soc Psychol 2003; 42:55-73.

15. Canetti L, Bachar E, Berry EM. Food and emotion. Behav Processes 2002; 60:157-64.

16. Edman JL, Yates A, Aruguete MS, DeBord KA. Negative emotion and disordered eating among obese college students. Eat Behav 2007; 6:30817.

17. Ganley RM. Emotion and eating in obesity: a review of the literature. Int J Eat Disord 1989; 8:343-61.

18. Ozier AD, Kendrick OW, Leeper JD, Knol LL, Perko M, Burnham J. Overweight and obesity are associated with emotion and stress-related eating as measured by the eating and appraisal due to emotions and stress questionnaire. J Am Diet Assoc 2008; 108:49-56.

19. Arnow B, Kenardy J, Agras SW. The Emotional Eating Scale: the development of a measure to assess coping with negative affect by eating. Int J Eat Disord 1995; 18:79-90.

20. Geliebert A, Aversa A. Emotional eating in overweight, normal weight, and underweight individuals. Eat Behav 2003; 3:341-7.

21. Levitan RD, Davis C. Emotions and eating behaviour: implications for the current obesity epidemic. University of Toronto Quarterly 2010; 79:783-99.

22. Vartanian LR. Disgust and perceived control in attitudes towards obese people. Int J Obes 2010; 34:1302-7.

23. Vartanian LR, Trewartha T, Vanman EJ. Disgust predicts prejudice and discrimination toward individuals with obesity. J Appl Soc Psychol 2016; 46:369-75.

24. Esnaola S, de Diego M, Elorriaga E, Martín U, Bacigalupe A, Calvo $M$, et al. Datos relevantes de la Encuesta de Salud del País Vasco 2013. Vitoria-Gasteiz: Departamento de Salud, Servicio de Estudios e Investigación Sanitaria; 2013.

25. Pereira de Sa C. Núcleo central das representaçoes sociais. Petrópolis: Editora Vozes; 1996.

26. Joffe H, Elsey J. Free association in psychology and the grid elaboration method. Rev Gen Psychol 2014; 18:173-85.

27. Wagner W. Word association in questionnaires: a practical guide to design and analysis. London: Methodology Institute, London School of Economics and Political Science; 1997. (Papers in Social Research Methods/Qualitative Series, 3).
28. Reinert M. Une méthode de classification descendante hiérarchique: application à l'analyse lexicale par contexte. Cah Anal Donnees 1983; 8:187-98.

29. Reinert M. Alceste une méthodologie d'analyse des données textuelles et une application: Aurelia De Gerard De Nerval. Bull Methodol Sociol 1990; 26:25-54.

30. Klein O, Licata L. When group representations serve social change: the speeches of Patrice Lumumba during the Congolese decolonization. Br J Soc Psychol 2003; 42:571-93.

31. Reinert M. Alceste (version 3.0). Toulouse: Images; 1996.

32. Lahlou S. A method to extract social representations from linguistic corpora. Japanese Journal of Experimental Social Psychology 1996; 35:278-91.

33. Kronberger N, Wagner W. Keywords in context: statistical analysis of text features. In: Bauer WM, Gaskell G, editors. Qualitative researching with text, image and sound: a practical handbook. London: Sage Publications; 2000. p. 299-317.

34. Vizeu B, Bousfield AB. Social representation, risk behaviours and AIDS. Span J Psychol 2009; 12:565-75.

35. Jansen W, Looij-Jansen P, Wilde E, Brug J. Feeling fat rather than being fat may be associated with psychological well-being in young Dutch adolescents. J Adolesc Health 2008; 42:128-36.

36. Silberstein L, Striegel R, Rodin J. Feeling fat: a woman's shame. In: Lewis HB, editors. The role of shame in symptom formation. Hillsdale: Lawrence Erlbaum Associates; 1987. p. 89-108.

37. Striegel-Moore M, McAvay G, Rodin J. Psychological and behavioral correlates of feeling fat in women. Int J Eat Disord 1986; 5:935-47.

38. Weiner B. Social motivation, justice, and the moral emotions: an attributional approach. Mahwah: Erlbaum; 2005.

39. Cuddy AJC, Fiske ST, Glick P. The BIAS map: behaviors from intergroup affect and stereotypes. J Pers Soc Psychol 2007; 92:631-48.

40. Harris MB, Waschull S, Walters L. Feeling fat: motivations, knowledge, and attitudes of overweight women and men. Psychol Rep 1990; 67:1191-202.

41. Bauman A, Phongsavan P, Schoeppe S, Owen N. Physical activity measurement a primer for health promotion. Promot Educ 2006; 13:92103.

42. Kahn EB, Ramsey LT, Brownson RC, Heath GW, Howze EH, Powell KE, et al. The effectiveness of interventions to increase physical activity: a systematic review. Am J Prev Med 2002; 22(4 Suppl):73-107.

43. Smith B, Bauman A. Physical environments. In: Kerr J, Weitkunat R, Moretti M, editors. ABC of behavior change: a guide to successful disease prevention and health promotion. Edinburgh: Elsevier; 2004. p. 139-52.

44. Peterson C, Seligman MEP. Helplessness and attributional style in depression: I and II. Tidsskrift for Norsk Psykoilogforening 1981; 18:3-18. 
45. Piggin J, Lee J. "Don't mention obesity": contradictions and tensions in the UK Change4Life health promotion campaign. J Health Psychol 2011; 16:1151-64.

46. Flegal KM, Graubard BI, Williamson DF, Gail MH. Cause-specific excess deaths associated with underweight, overweight, and obesity. JAMA 2007; 298:2028-37.

47. Ledford CH. Obesity, adolescence. In: Gullotta T, Bloom M, editors. The encyclopedia of primary prevention and health promotion. New York: Kluwer/Plenum Press; 2003. p. 750-6.

48. NGA Center for Best Practices . Preventing obesity in youth through school-based efforts. Washington DC: NGA Center for Best Practices; 2003 .

\section{Resumen}

Este estudio examina de qué forma la juventud representa la gordura colectivamente y determina las emociones que suscita. Entender cómo se construye la gordura socialmente por parte de la gente joven, es crucial para crear programas que puedan lidiar mejor con ella. Para ello se llevó a cabo un ejercicio de asociación libre, suscitado por la palabra "gordura", que fue respondido por 200 personas de la Comunidad Autónoma del País Vasco (España). Su contenido fue analizado a través de su léxico, usando el software Alceste. Los resultados mostraron que la representación que relacionaba la gordura con la salud fue en su mayor parte descriptiva, y no estaba conectada con ninguna respuesta emocional o relacionada con el riesgo. Sin embargo, la gordura fue también representada como una presión social, relacionada con la estigmatización, y altamente correlacionada con emociones negativas como la tristeza, inseguridad, vergüenza, angustia, soledad, lástima o ira. Es decir, las emociones relacionadas con el riesgo y negativas se vincularon a una no aceptación social, y no a problemas de salud. Por tanto, la conclusión es que la gordura se transmite partiendo desde el temor y no desde una construcción positiva de lo que significa la salud.

Emociones; Obesidad; Peso Corporal; Adulto Joven
49. Wolf MC, Cohen KR, Rosenfeld JG. Schoolbased interventions for obesity: current approaches and future prospects. Psychol Sch 1985; 22:187-200.

50. Pyle S, SharkeyT, Yetter G, Felix E, Furlong MJ, Poston WSC. Fighting an epidemic: the role of schools in reducing childhood obesity. Psychol Sch 2006; 43:361-76.

51. Williams PG, Holmbeck GN, Greenley RN. Adolescent health psychology. J Consult Clin Psychol 2002; 70:828-42.

\section{Resumo}

O estudo examina as representações coletivas dos jovens em relação à gordura e identifica as emoções que suscita. Entender a construção social da gordura pelos jovens é crucial para poder criar programas para lidar melhor com a questão. Um exercício de associação livre evocada pela palavra "gordura" foi respondido por 200 pessoas da Comunidade Autônoma do País Basco (Espanha), e o conteúdo foi submetido a análise lexical com o uso do programa Alceste. Os resultados mostram que a representação da gordura em relação à saúde era predominantemente descritiva, sem associação com o risco ou com qualquer resposta emocional. Entretanto, a gordura também era representada enquanto questão de pressão social relacionada à estigmatização, fortemente correlacionada com emoções negativas como tristeza, insegurança, embaraço, ansiedade, solidão, pena ou raiva. Ou seja, as emoções arriscadas e negativas estiveram ligadas à não-aceitação social, e não a problemas de saúde. Portanto, a conclusão é que a representação da gordura é transmitida por medo, e não por uma construção positiva da saúde.

Emoções; Obesidade; Peso Corporal; Adulto Jovem
Submitted on $16 /$ Nov/2017

Final version resubmitted on 26/Mar/2018

Approved on 02/May/2018 